\title{
SPOTTED
}

\section{Spotted around the web: Ultrasound, microbial metabolites, profound autism}

BY JILL ADAMS

18 FEBRUARY 2022 